\title{
Septic Pulmonary Embolism Associated with Acinetobacter Pneumonia
}

\author{
Acinetobacter Pnömonisi Ilişkili Septik Pulmoner Emboli
}

Emine Afşin

\section{Abstract}

Septic pulmonary embolism is an infective lung disease that leads to infarction in the pulmonary arteries and bilateral multiple nodules and/or cavitations in the lung parenchyma resulting from the circulation of thrombus in the bloodstream as infected with microorganisms in the primary infectious focus. A 58-yearold case we have presented was hospitalized with the diagnosis of COPD exacerbation and was taken to the intensive care unit to be monitored in the invasive mechanical ventilator because of fever, cough, increased dyspnea and development of bilateral diffuse infiltration encountered by chest $x$-ray. Thoracic computed tomography encountered peripherally localized and partly cavitary nodules, infiltration, mediastinal lymphadenomegaly with a maximum diameter of 1 $\mathrm{cm}$, bilateral pleural effusion and feeding vessel sign. After exitus of the patient who was unresponsive to broad spectrum antibiotic and antifungal therapy; tracheal aspirate culture test indicated the growth of Acinetobacter baumannii /calcoaceticus (resistant to all the antibiotics in the antibiogram). The detection of Gram Negative Pneumonia has been rarely reported in the etiology of septic pulmonary embolism that presents a high mortality rate, therefore, we aimed to discuss that case in the light of literature data.

Key words: Acinetobacter, pneumonia, septic pulmonary embolism.

\begin{abstract}
Özet
Septik pulmoner emboli, birincil enfeksiyon kaynağındaki mikroorganizma içeren trombüsün dolaşıma karışması sonucu, pulmoner arterlerde enfarkt ve akciğer parankiminde bilateral multipl nodül ve/veya kaviteye yol açan nadir bir enfektif akciğer hastalığıdır. Olgumuz, 58 yaşında KOAH alevlenme tanısıyla yatırılmış olup, yatışının 4. gününde ateş, öksürük, nefes darlığında artış, akciğer grafisinde bilateral yaygın infiltrasyon gelişmesi üzerine yoğun bakımda invazif mekanik ventilatörde takip edildi. Toraks bilgisayarlı tomografisinde; periferik yerleşimli ve bazıları kaviter olan nodüller, infiltrasyon, maximum $1 \mathrm{~cm}$ olan mediastinal lenfadenomegali, bilateral plevral effüzyon ve besleyici damar belirtisi izlendi. Geniş spektrumlu antibiyotik ve antifungal tedaviye yanit alınamayan hastanın exitusundan sonra trakeal aspirat kültüründe Acinetobacter baumannii / calcoaceticus (antibiyogramındaki antibiyotiklerin tümüne dirençli) üremesi saptandı. Mortalitesi yüksek olan septik pulmoner emboli etyolojisinde gram negatif pnömoni saptanması nadir bildirilmiş olup, bu nedenden dolayı olguyu literatür eşliğinde tartışmayı amaçladık.
\end{abstract}

Anahtar Sözcükler: Acinetobacter, pnömoni, septik pulmoner emboli.

Department of Chest Diseases, İzet Baysal State Hospital, Bolu, Turkey

İzzet Baysal Devlet Hastanesi, Göğüs Hastalıkları Kliniği, Bolu

Submitted (Başvuru tarihi): 08.03.2020 Accepted (Kabul tarihi): 01.07.2020

Correspondence (iletişim): Emine Afşin, Department of Chest Diseases, İzzet Baysal State Hospital, Bolu, Turkey

e-mail: emineafsin@yahoo.com 
Septic pulmonary embolism is an infective lung disease that leads to infarction in the pulmonary arteries and bilateral multiple nodules and/or cavitations in the lung parenchyma resulting from the circulation of thrombus infected with microorganisms in the primary infectious focus in the bloodstream (1). The clinical symptoms and radiological findings of the case we have presented were consistent with septic pulmonary embolism and its differential diagnoses were eliminated. Acinetobacter baumannii/calcoaceticus grew in the tracheal aspirate culture of the patient who became exitus due to unresponsiveness to broad spectrum antibiotic and antifungal therapy. We have reported this case for the presence of rarely reported septic pulmonary embolism associated with Acinetobacter pneumonia in the literature, its high mortality rate and necessity of early treatment with broad spectrum antibiotic therapy because of its high mortality rate.

\section{CASE}

The 58-year-old male patient was monitored as diagnosed with COPD and admitted with diagnosis of COPD exacerbation due to the increased complaints of cough, sputum and dyspnea. He had no feature except previous cholecystectomy operation in his medical history. His history of smoking cigarette was 35 pack/year and he had no smoking since 4 years. His measures were as following: Fever: $38.5^{\circ} \mathrm{C}$, TA: $110 / 60 \mathrm{mmHg}$, Pulse: $94 / \mathrm{min}$, and respiratory rate: $20 / \mathrm{min}$. The baseline valves at admission to the ward were as following: CReactive Protein (CRP): $31 \mathrm{mg} / \mathrm{dL}$ (normal range:0-5 $\mathrm{mg} / \mathrm{dL}$ ), Leukocytes: $8600 / \mathrm{mm}^{3}$ and sedimentation: 10 $\mathrm{mm} / \mathrm{h}$. Decompensated respiratory acidosis developed on the 4th day of admission and the patient was taken to the intensive care unit as intubated because of unresponsiveness to non-invasive mechanical ventilator treatment. The patient had no pathological lesion in the chest $\mathrm{x}$-ray (Figure 1) at admission while blood parameters at admission to the intensive care unit (Figure 2) were CRP: $137 \mathrm{mg} / \mathrm{d}$, Leukocytes: $33400 / \mathrm{mm}^{3}$ and neutrophil rate: $32 \%$, consequently initial ceftriaxone treatment was stopped and meropenem treatment was initiated. Linezolid was added to the treatment regimen in the patient with persisting high fever and CRP levels accompanied with diffuse infiltrations as encountered in the chest $x$-ray. Anidulafungin treatment was initiated because of unresponsiveness to the treatment and detection of oral candida lesions. The creatinine level raised to $3.68 \mathrm{mg} / \mathrm{dL}$ whereas creatinine levels were normal during monitoring and the patient was taken to dialysis due to development of anuria. Peripher- ally located and partly cavitary nodules, infiltration, mediastinal lymphadenomegaly with a maximum diameter of $1 \mathrm{~cm}$, bilateral pleural effusion and feeding vessel sign were encountered in the thoracic computed tomography (CT) performed in the next day (Figure 3). No thoracentesis was performed since pleural effusion was minimal. Septic embolism was considered in the patient, immune markers for Wegener Granulomatozis as well as ARB and mycobacteria culture from the tracheal aspirate for tuberculosis were tested for differential diagnosis. Sedimentation and rheumatoid factor levels were $140 \mathrm{~mm} / \mathrm{h}$ and $8.4 \mathrm{IU} / \mathrm{mL}$ (Range: $0-30 \mathrm{IU} / \mathrm{mL}$ ), respectively, ANA, cANCA, p-ANCA, PR3-ANCA assays were negative. No metastasis was considered since baseline chest $x$-ray at admission was normal. No finding of infective endocarditis was detected in the transthoracic echocardiography. No microbial growth was found in the blood, urine and catheter cultures. No hyphe was encountered in the tracheal aspirate culture while fungal culture indicated no growth. The patient became exitus on the 14th day of admission in the intensive care unit. $A$. baumannii /calcoaceticus grew in the tracheal aspirate culture 4 days after exitus. The culture test material was tested using VITEK 2 system in accordance with the recommendations of European Committee on Antimicrobial Susceptibility Testing (EUCAST) and tested respiratory tract samples were found resistant to all the antibiotics listed in the guideline.

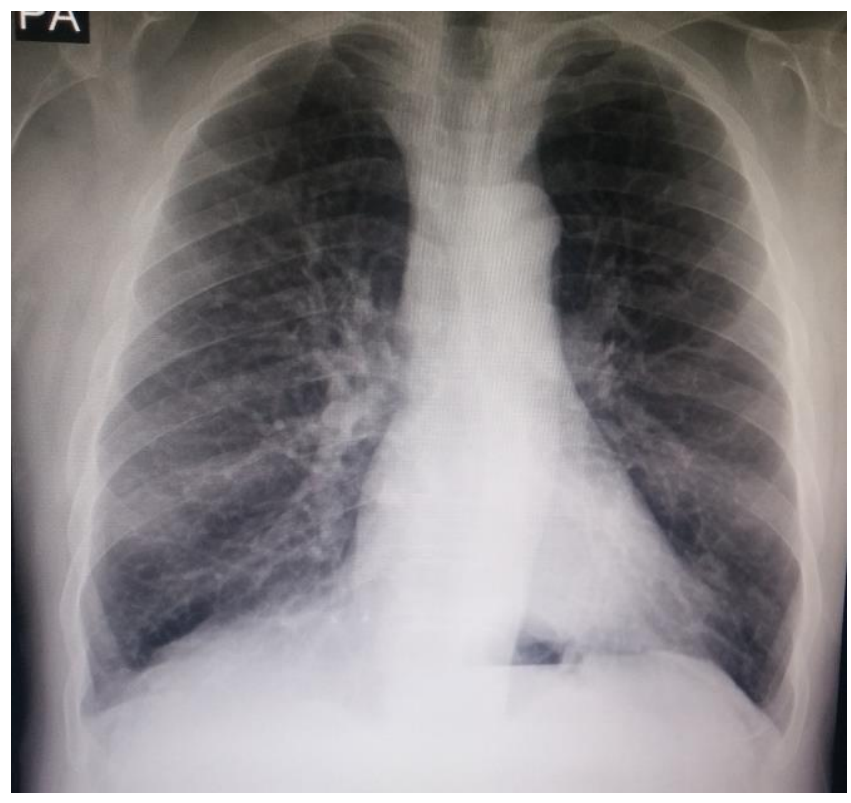

Figure 1: Chest x-ray at admission to hospital 


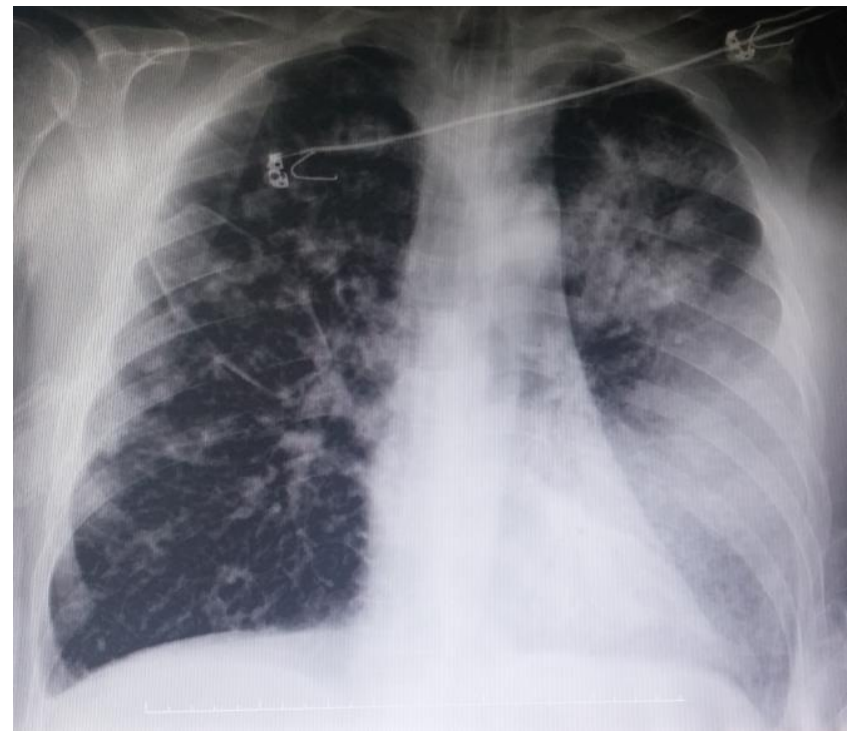

Figure 2: Chest $x$-ray in the intensive care unit

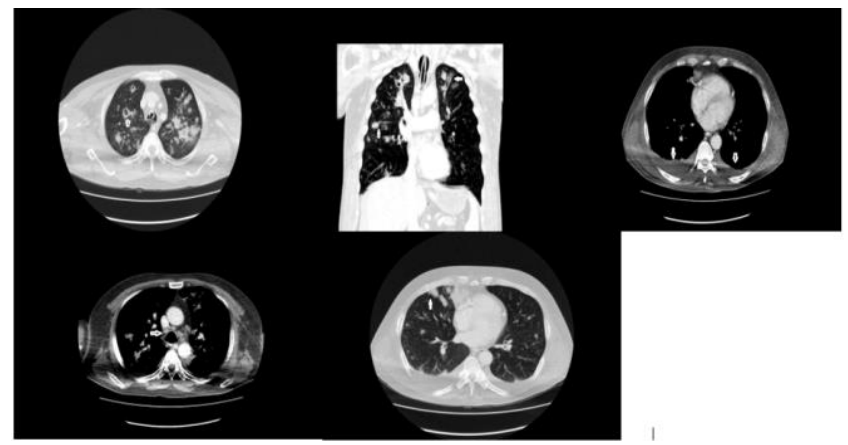

Figure 3: Thoracic tomography reveals partly cavitary nodules, feeding vessel sign, bilateral pleural effusion, mediastinal lymphadenomegaly, wedge-shaped peripheral lesions and parenchymal infiltration

\section{DISCUSSION}

Septic pulmonary embolism is an infective lung disease that leads to infarction in the pulmonary arteries and bilateral multiple nodules and/or cavitations in the lung parenchyma resulting from the circulation of thrombus infected with microorganisms in the primary infectious focus in the bloodstream (1). It frequently emerges secondary to oropharyngeal infections, right-sided infective endocarditis, central venous catheter infection, infected pacemaker, liver abscess, peritonsillar abscess (Lemierre's syndrome), osteomyelitis, mastoiditis, A-V shunts in hemodialysis patients, septic abortus, skin-soft tissue infections and administration of intravenous drugs $(1,2)$. The essential characteristics of septic pulmonary embolism are fever, pulmonary infiltration and presence of an extrathoracic infection focus that may cause this infiltration. The progression to septic fever, dyspnea, cough, pleuritic chest pain progressing to respiratory distress and hemoptysis in the advanced period are monitored in the cases with septic pulmonary embolism $(3,4)$. The symptoms cough, fever and increased dyspnea were present in also our case.

Chest $\mathrm{x}$-ray may be normal; hence, thoracic tomography is superior for diagnosis (1). The most common thoracic CT findings of septic pulmonary embolism have been defined as peripheral nodules, wedge shaped peripheral lesions, cavitations and feeding vessel sign, respectively (5). The lesions are located in the neighborhood of pleu$\mathrm{ra}$ and at the end of the vessels. This appearance is termed as feeding vessel sign indicating hematogenous source of the lesion and it may be encountered also in the lung metastases. The lesions may lead to cavitation and suppuration by rapid progression (2). Cavitation may occur in also aseptic embolisms; however, it should be taken into account that a bacterial infarction may be added onto the thromboembolic infarction in the presence of cavitation. Hilar or mediastinal lymph node growth may accompany when acute septic pulmonary embolism is massive (6). Partly cavitary nodules, mediastinal lymphadenomegaly with diameter of maximum $1 \mathrm{~cm}$, infiltration and bilateral pleural effusion were encountered in our case by Thoracic CT. The patients are mostly diagnosed based on primary infection focus and tomography findings (7). The blood and urine cultures revealed no growth while fungal direct exam and fungal culture indicated no feature in our case. The growth of Acinetobacter was detected in the tracheal aspirate culture after the patient became exitus.

Tuberculosis, fungal and Gram (-) infections, parasitic infections (cyst hydatid), metastasis, lymphoma, benign and malignant neoplasms of the lung, rheumatoid arthritis, Wegener granulomatosis, Churg-Strauss syndrome and sarcoidosis should be considered in differential diagnosis (8). Echocardiography should be performed in the patients with septic pulmonary embolism because tricuspid valvular vegetation, valvular regurgitation and paravalvular abscesses may be identified in these cases. Transesophageal echocardiography is a superior diagnostic technique to transthoracic echocardiography in imaging small vegetation (5). No pathological image compatible with endocarditis was encountered in the echocardiography of our case.

Sakuma et al. (9) have reported that infective endocarditis was present in $11 \%$ of the cases with septic pulmonary embolism and that a higher frequency of fungal embolism was found compared with bacterial embolism in these patients with mostly underlying hematogenous malignancies such as lymphoma and leukemia. S. aureus, K. pneumoniae and Viridans Streptococci are the most 
commonly detected infectious agents in the blood cultures $(7,9,10)$. Chou et al. (11) have reported that multiorgan dysfunction syndrome developed in $85 \%$ of the patients and acute respiratory distress syndrome ARDS was the most commonly seen organ failure (75\%). Liver abscess (40\%) was the most frequently seen primary infectious focus followed by pneumonia (25\%). The most prevalent two casual pathogens were $K$. pneumoniae (50\%) and S.aureus (35\%). Serum creatinine, arterial partial carbon dioxide pressure, APACHE II and (SOFA) (The Acute Physiology and Chronic Health Evaluation and Sequential Organ Dysfunction Evaluation) scores were significantly higher in the exitus patients while also acute kidney injury, disseminated intravascular coagulation and lung abscess were determined with higher rates in those patients than the survivors. Intrahospital mortality rate was reported as $30 \%$. The patients with septic pulmonary embolism that requires treatment in the intensive care unit, particularly those with pneumonia and liver abscess, were found to be associated with high mortality rates. The patients with pneumonia $(60 \%)$ as the primary source of pulmonary embolism indicated manifested the highest mortality rate. Acute kidney failure developed during monitoring our case and he was taken to hemodialysis. No regression could be obtained in hypercapnia despite implementation of the appropriate ventilation strategies and APACHE II score was high.

It has been reported that nodules in the Gram-positive septic embolism were larger than those in the Gramnegative septic embolism. Cavitation and air bronchogram were more frequently seen in the Gram-positive embolism while halo and feeding vessel sign with groundglass intensity around a nodule were more commonly monitored in the Gram-negative embolism (10). Both cavitary nodules and feeding vessel sign were present in our case.

Septic pulmonary embolism is not only associated with increased mortality and prolonged hospital stay duration, it is also related with complications such as abscess, empyema and also bronchopleural fistula that requires different therapeutic interventions (12). Acinetobacter as an aerobic gram negative cocobacillus is an important pathogen in nosocomial pneumonia. However, it may rarely cause community-acquired pneumonia. A. baumannii species of Acinetobacter genus is a common cause of community acquired pneumonia in the tropi$\mathrm{cal} / \mathrm{subtropical}$ region and also other places with a warm and humid climates (13). It was identified as the hospitalacquired pneumonia agent in our case. Although, Aci- netobacter strains that cause community-acquired infections are usually sensitive to aminoglycosides, broadspectrum penicillin, ceftazidime, kinolon, imipenem ve ciprofloxacin (13), Acinetobacter strain was reported to be resistant in our case. Wade et al. (12) have reported Acinetobacter strain that grew in the blood culture as the responsible infectious agent for the septic pulmonary embolism that developed due to pneumonia in an 11 month-old infant (12). The presence of bacteremia explains the development of septic pulmonary embolism. In also our case; no other infectious agent that may explain the etiology of septic pulmonary embolism was identified and inability to detect the growth in the blood culture may be resulting from technical and laboratory circumstances. As a conclusion; pneumonia also should be beard in mind in the etiology of septic pulmonary embolism and the administration of broad spectrum antibiotic therapy should be initiated early for this clinical manifestation with high mortality rate.

\section{CONFLICTS OF INTEREST}

None declared.

\section{AUTHOR CONTRIBUTIONS}

Concept - E.A.; Planning and Design - E.A.; Supervision E.A.; Funding - E.A.; Materials - E.A.; Data Collection and/or Processing - E.A.; Analysis and/or Interpretation E.A.; Literature Review - E.A.; Writing - E.A.; Critical Review - E.A.

\section{YAZAR KATKILARI}

Fikir - E.A.; Tasarım ve Dizayn - E.A.; Denetleme - E.A.; Kaynaklar - E.A.; Malzemeler - E.A.; Veri Toplama ve/veya İşleme - E.A.; Analiz ve/veya Yorum - E.A.; Literatür Taraması - E.A.; Yazıyı Yazan - E.A.; Eleştirel İnceleme - E.A.

\section{REFERENCES}

1. Oh HG, Cha SI, Shin KM, Lim JK, Kim HJ, Yoo SS, et al. Risk factors for mortality in patients with septic pulmonary embolism. J Infect Chemother 2016; 22:553-8. [CrossRef]

2. Jorens PG, Van Marck E, Snoeckx A, Parizel PM. Nonthrombotic pulmonary embolism. Eur Respir J 2009; 34:452-74. [CrossRef]

3. Fedullo PF. Pulmonary thrombo embolism. In: Murray JF, Nadel JA, eds. Textbook of respiratory medicine. 3rd ed. W.B. SaundersCompany; 2000: 1503-31. 
4. Shiota Y, Arikita H, Horita N, Hiyama J, Ono T, Ohkawa $\mathrm{S}$, et al. Septic pulmonary embolism associated with periodontal disease: reports of two cases and review of the literature. Chest 2002; 121:652-4. [CrossRef]

5. Iwasaki Y1, Nagata K, Nakanishi M, Natuhara A, Harada $H$, Kubota $Y$, et al. Spiral CT findings in septic pulmonary emboli. Eur J Radiol 2001; 37:190-4. [CrossRef]

6. Cook RJ, Ashton RW, Aughenbaugh GL, Ryu JH. Septic pulmonary embolism: presenting feature sand clinical course of 14 patients. Chest 2005; 128:162-6. [CrossRef]

7. Morris TA, Fedullo PF. Pulmonary Thromboembolism. In: Mason RJ, Murray JF, Nadel JA. Eds. Respiratory Medicine. 5th ed. Saunders; 2010: 1216. [CrossRef]

8. Tanrıverdi F, Çelik GK, Günaydın GP, Coşkun S, Erşen T. Intravenöz uyuşturucu madde bağımlısı hastada gelişen septik pulmoner emboli. JAEMCR 2014; 5:180-2. [CrossRef]
9. Sakuma M, Sugimura K, Nakamura M, Takahashi T, Kitamukai $O$, Yazu $T$, et al. Unusual pulmonary embolism: septic pulmonary embolism and amniotic fluid embolism. Circ J 2007; 71:772-5. [CrossRef]

10. Kwon WJ, Jeong YJ, Kim KI, Lee IS, Jeon UB, Lee SH, et al. Computed tomographic features of pulmonary septic emboli: comparison of causative microorganisms. J Comput Assist Tomogr 2007; 31:390-4. [CrossRef]

11. Chou DW, Wu SL, Chung KM, Han SC, Cheung BMH. Septic pulmonary embolism requiring critical care: clinicoradiological spectrum, causative pathogens and outcomes. Clinics (Sao Paolu) 2016; 71:562-9. [CrossRef]

12. Wade P, Ananthan A, David J, Ghildiyal R. A case of Acinetobacter septic pulmonary embolism in an infant. Case Rep Infect Dis 2016; 2016:5241571. [CrossRef]

13. Chen MZ, Hsueh PR, Lee LN, Yu CJ, Yang PC, Luh KT. Severe community-acquired pneumonia due to Acinetobacter baumannii. Chest 2001; 120:1072-7. [CrossRef] 